\title{
Orginal Antiele
}

\section{Contemporary symbols in the space of Baku}

\author{
Elżbieta Kaczmarska \\ Faculty of Architecture and Fine Arts; Andrzej Frycz Modrzewski Krakow University; \\ Gustaw Herlinga-Grudziński St. 1, 30-705 Kraków, Poland; \\ kaczmarskaelzbieta@poczta.onet.pl (ID)0000-0002-4271-8462
}

\begin{abstract}
When performing even a cursory analysis of the visual image of contemporary Baku, the capital of Azerbaijan, one simply cannot ignore its ancient history, the political influence of nearby powers and the almost age-old dependence on Soviet Russia. The regaining of independence in 1991, associated with the policy of then-national leader Heydar Aliyev, stimulated the young country's ambition to open up to the world and organise an international cultural event. The preparation for the Eurovision Song Contest in 2012 initiated another construction boom in the history of Baku, fuelled with petrodollars, and became an occasion to present a new vision of the capital. In the years 2007-2012, numerous new cultural, artistic and sports buildings were constructed and which are now a hallmark and symbol of contemporary Baku. One such building, which creates a new, futuristic city space and is presented in the article, is the Heydar Aliyev Centre, a centre of art and museum designed by Zaha Hadid. The author notes the creative intent, external appearance and structure of the building, as well as new means of expression in creating place-based ambience. Also noted were the use of contemporary art in the creation of attractive utilitarian spaces. Other presented buildings display the ages-old symbols of the 'Land of Fire' in a new way and are embedded into the contemporary panorama of the city.
\end{abstract}

Keywords: history; symbols; form; Flame Towers; construction boom; urban space; public space; contemporaneity; futuristic vision; Baku; Azerbaijan

\section{Introduction}

Of the three capitals of Transcaucasia - Tbilisi, Erevan and Baku — it is Baku that has been developing the quickest in the twenty-first century. The city, located on the shore of the Caspian Sea, in the in the southern zone of the Absheron Peninsula, is the capital of Azerbaijan ${ }^{1}$ [1][2].

1 Contemporary outlooks on Azerbaijan's historic sites and its modern image are not widely known. Two Polish-language publications can be listed, however. The first is a work by Tadeusz Świętochowski-a Pole, orientalist and lecturer at American universities and at Germany's Heidelberg University, the author of numerous academic works on the history and contemporary problems of 
This metropolis with a population of 2 million, which is a quarter of the country's population, is characterised by high ethnic diversity and an interesting structure of space [3] [4] [5]. Here, areas of traditional development and singular modern buildings or complexes are located on sites that are attractive in terms of the landscape and define the visual perception of the city.

The ancient part of the city currently occupies a small, walled area that is near the coast. This 'Inner City', separated from the remaining development and isolated by existing fortifications, has retained its past psychological atmosphere and irregular urban layout stemming from defensive strategies and climate conditions, in addition to numerous historical monuments. ${ }^{2}$

At present, new projects in the capital, that stand out through atypical and futuristic forms, have been sited in various areas of the seaside boulevard or in its immediate area, as well as in the city's north-eastern zone. The areas in question, occupying a large territory, are linked by comfortable vehicular circulation, including marshrutkas, the railway and a modern underground railway, and are also equipped with park areas. The latter enable the city's cross-ventilation - which is not easy when winds constantly change direction, which is also a feature of the peninsula's climate.

The development of Baku has been tied with natural resources, particularly oil and natural gas, for ages. In the twenty-first century, it makes use of the current economic and political situation to awe the world with the new image of the capital. Buildings with cosmic shapes and many new facilities associated with culture, art and sports were built at the start of the new century [6], [7]. The new symbols of Baku, which build the ambience of places and the physical image of the city, mark another period in the life of the city and the country since it regained independence in 1991 and after the fall of the Soviet Union. ${ }^{3}$ They are also a monument to the Aliyev family which holds political and economic power in the country and which makes exaggerated references to the engineering traditions and skills of contemporary structural engineers and contractors. Among the gigantic monuments to power there is, among others, the Heydat Aliyev Centre, which houses a museum and is dedicated to the first president of Azerbaijan and the architect of its independence.

the Middle East and the Muslim nations of the former USSR, particularly Azerbaijan. The second Polish-language publication is Azerbejdżan, publ. Oficyna Wydawnicza „Rewasz”, Pruszków 2014, commissioned by the Ministry of Culture and Tourism of the republic of Azerbaijan and on the initiative of His Excellency the Ambassador of the Republic of Azerbaijan in Poland Hasan Hasanov, PhD.

2 They include: the quintessence of Baku's Old Town - the buildings along Asaf Zeynalli and the Maiden Tower, the surviving fortifications; the heart of the capital - the palace complex of the palace of the Shirvanshahs., the caravanserais and city baths; residences of the wealthy from the turn of the twentieth century. The genius loci of this location is also associated with a place conducive to remembrance and meditation sited near the Old Town - the Path of Martyrs, as well as a region to the south of Baku - Gobustan, with prehistoric carvings and mud volcanoes.

3 Azerbaijan is a country of contrasts. The extraordinary wealth of the capital and the visible prosperity of a number of significant cities border on the clear poverty of smaller cities. The life of towns and scattered villages is as calm as it was centuries ago, with not much being built; the panorama of their landscape is dominated by the majestic and frightening Greater Caucasus and it is this proximity that is their wealth.

The current dynamic development of Baku and the construction of newer and newer spectacular buildings can be seen as associated with the threat of uneven expansion. While all of the country's energy and financial resources are pooled in the formal zone, the unprivileged majority remains forgotten. Socially and spatially marginalised, these people will be forced to move to districts further away, where they can potentially form areas of poverty endangered by rising crime rates and violence [6]. 


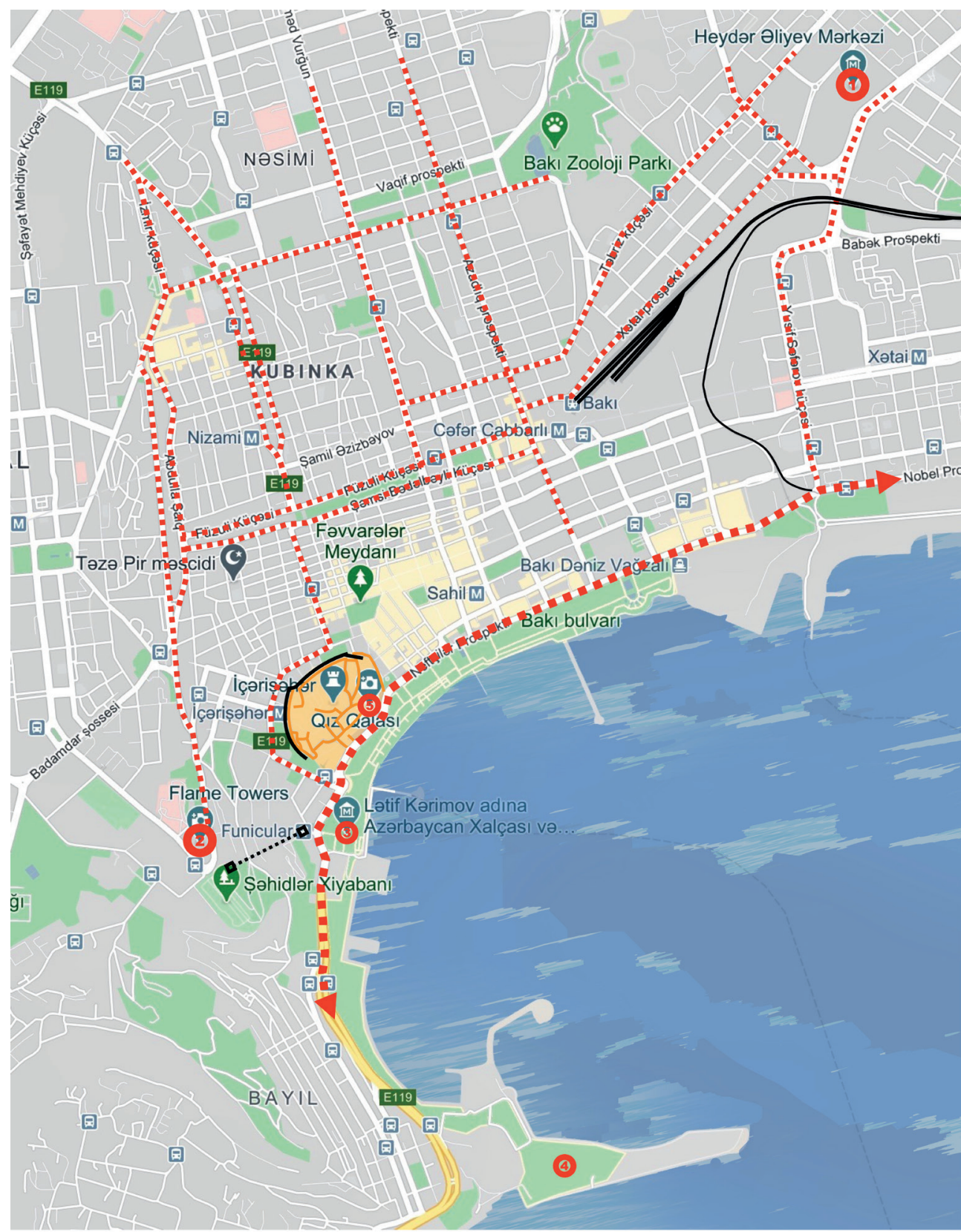

(1) Heydar Aliyev Center, design by Zaha Hadid

(2) Flame Towers, design by HOK

(3) Azerbaijan National Carpet Museum, design by Franz Janz

(4) Baku Cristal Hall, design by GMP Architekten

(5) Maiden Tower

Fig. 1. Baku—structure of the city and selected elements that crystallise its spatial layout—original work based on Google Maps, 2020 


\section{The Heydar Aliyev Centre by Zaha Hadid}

The building, hidden deep in the city's northern zone, is a legend, an aesthetic feast, one of the best works of 'ingenious Zaha'- the Heydar Aliyev Centre is Azerbaijan's main building to feature this use. The soft, dynamic forms of the new building clearly depart from the distinct administrative and residential buildings of the Soviet period found in this area of the city. Monumental, Socialist Realist style buildings are a panoramic background of its 'second plane' and clearly contrast in terms of function, scale and style.

The Heydar Aliyev Centre is an atypically shaped building. Its external reflection inspires awe, fascinates and intimidates, while also stimulating the imagination. It may bring to mind a poorly curled up carpet, a handkerchief thrown down from space or a lost, gigantic brooch. The fluid, undulating waves of its roof can bring to mind a stormy sea and the oil that gushes out from it and falls heavily downwards - the age-old wealth of the country. To pragmatists, this work can denote a reaction and rebellion against the rigid architecture of Soviet times, or perhaps it is a reference to the ornaments of Islamic calligraphy and elements of traditional Azeri architecture ${ }^{4}[8]$.

4 "The Center, designed to become the primary building for the nation's cultural programs, breaks from the rigid and often monumental Soviet architecture that is so prevalent in Baku, aspiring instead to express the sensibilities of Azeri culture and the optimism of a nation that looks to the future'. and 'Fluidity in architecture is not new to this region. [...] Our intention was to relate to that historical understanding of architecture, not through the use of mimicry or a limiting adherence to the iconography of the past, but rather by developing a firmly contemporary interpretation, reflecting a more nuanced understanding" [8]. 

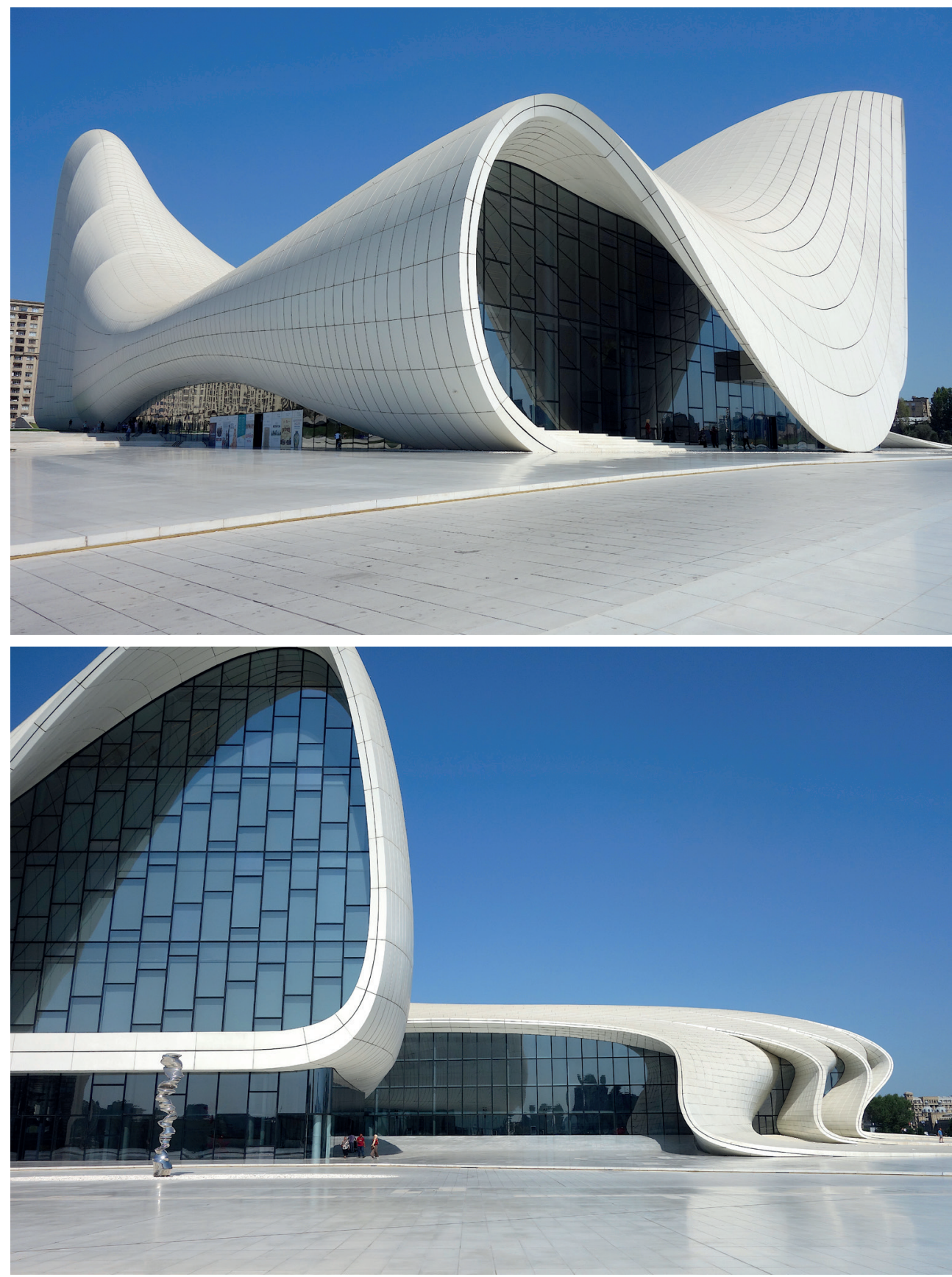

Fig. 2-3. Heydar Aliyev Center, design by Zaha Hadid. Photo by E. Kaczmarska, 2018 
However, it appears that the building that has become the symbol of Baku's twenty-first-century architecture has two practical functions: to present its designer and her 'artistic thinking'; and in the museum section, to commemorate the first president of independent Azerbaijan, Heydar Aliyev, a national hero and a man offered almost divine praise, the father of the current president Ilham Aliyev. Zaha Hadid fulfilled both of these tasks. The design was completed after an international competition in the years 2007-2012, also in connection with the construction of many new buildings that accompanied the Eurovision Song Contest, which took place in 2012 in Baku.

The centre and museum form one mixed-use building that has eight levels (it has a height of 74 metres). It includes an auditorium with 1000 seats, a temporary exhibition area, a conference centre, spaces for workshops and a museum. The massing of the centre harmoniously blends with its interior, while also being in a relationship with the nearby square.

The centre and all of its functions, apart from the entrance, are laid out into a fluid form with a continuous surface. The centre's functional spaces, without any supports, are surrounded by a curvilinear skin made from glass fibre reinforced concrete (GFRC) and glass fibre reinforced polyester. This cladding (which can also suggest a tent and reference the nomadic traditions of the Azeri) is suspended by a load-bearing structure comprised of a complex system of concrete and steel elements. The 'satin' finish of the building's surface resulted from the application of semi-reflective glass that causes the building's appearance to change depending on the time of day and season of the year, and the interior and exterior enter into a harmonious relationship.

The interior of the building, coloured white, is filled with light and half-shadows. The rhythm of softly profiled stairs creates an undulating internal amphitheatre. White American oak was used as a finishing material, which provides good parameters under conditions of changing weather associated with temperature and humidity, which resulted in a uniform texture, an effect of lightness and luminosity, as well as excellent acoustic properties [9] [10]. 

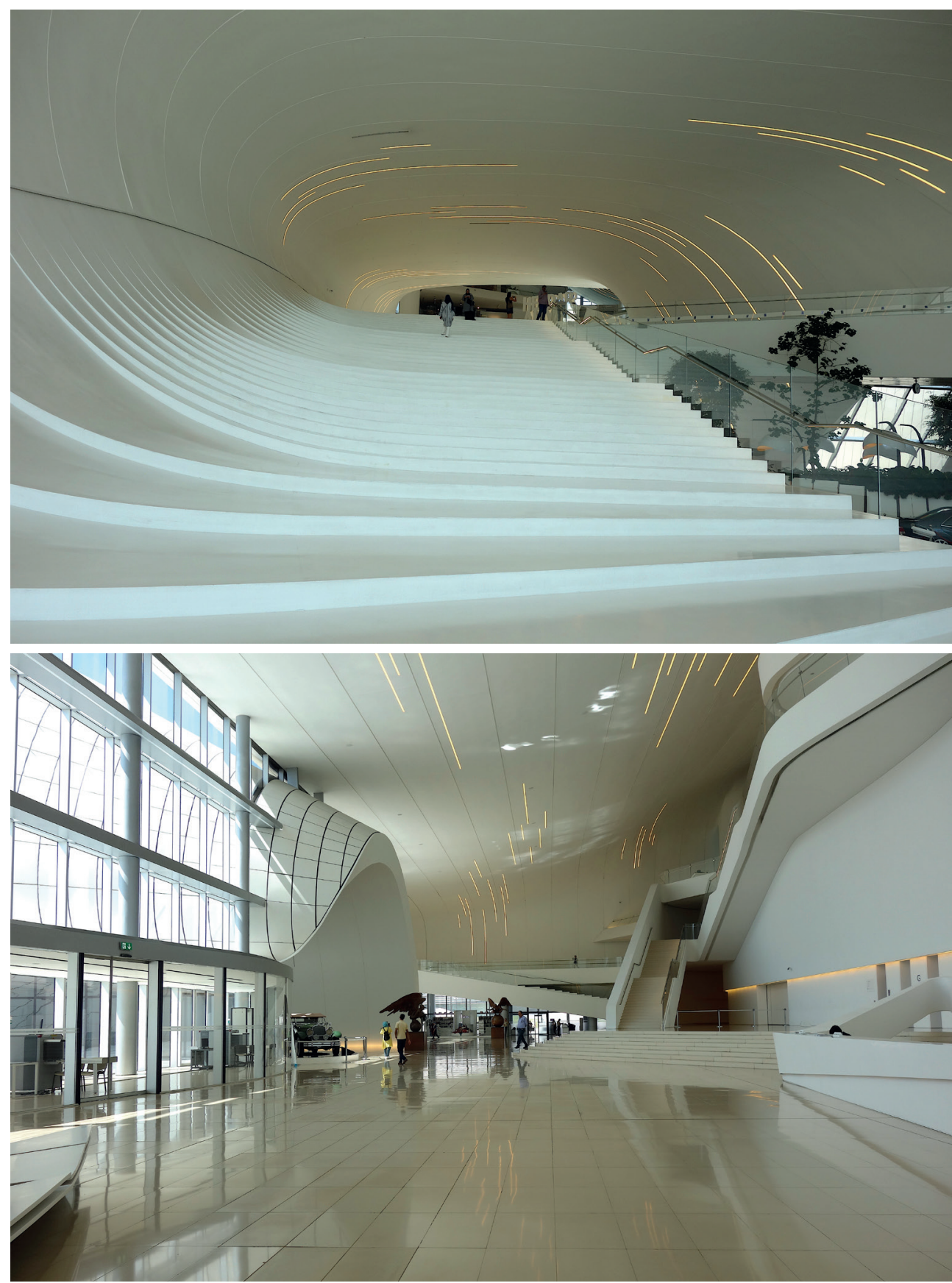

Fig. 4-5. Heydar Aliyev Center, design by Zaha Hadid; interior. Photo by E. Kaczmarska, 2018 
The museum is located on a ten-hectare green lawn of varying height, maintaining the principle of the undulation of the place and the building. Located on a slightly elevated plateau, the building has interesting surroundings, to which unpretentious yet varied sculptural motifs have been introduced. Families of gigantic red and blue snails march across the grass, serving as a source of shade. A green rabbit of similar size sits as if slightly to the side. Their saturated colours are probably a distant reflection of the Azerbaijani flag, but their practical use is different. They provide protection from the sun and wind and are a pleasant spot to rest at. This space, accessible from the side of the driveway, is perceived as pleasant. The facade of a likewise new sports hall, designed in a mellow style, forms a direct, northern screen for this space. The entirety of the centre's space is a sophisticated work of art and design; it escapes traditional analyses and evaluations. It is difficult to speak of windows, roofs or staircases here, or other supplementations to this form for that matter; it is a complete work.

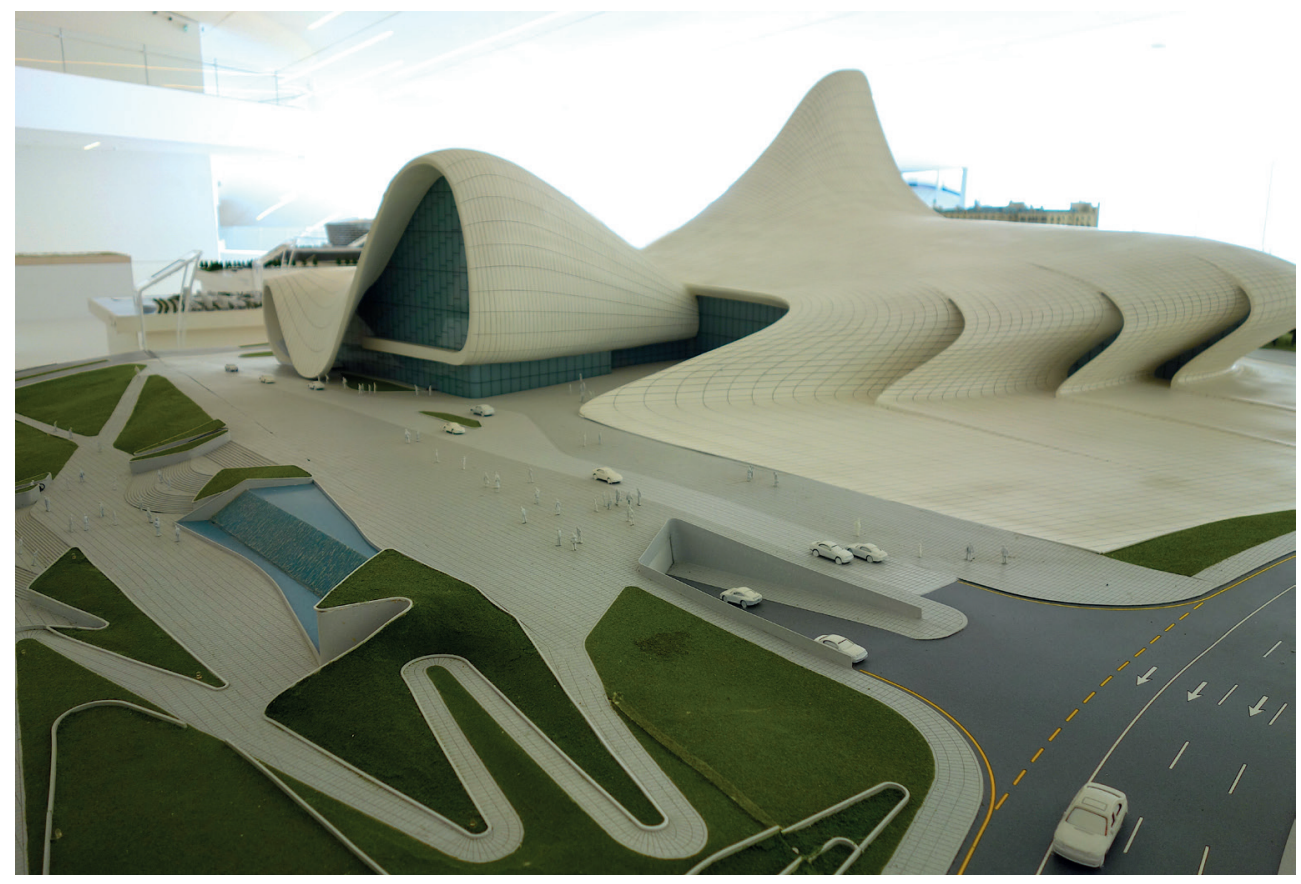

Fig. 6. Heydar Aliyev Center, design by Zaha Hadid; mock-up. Photo by E. Kaczmarska, 2018 

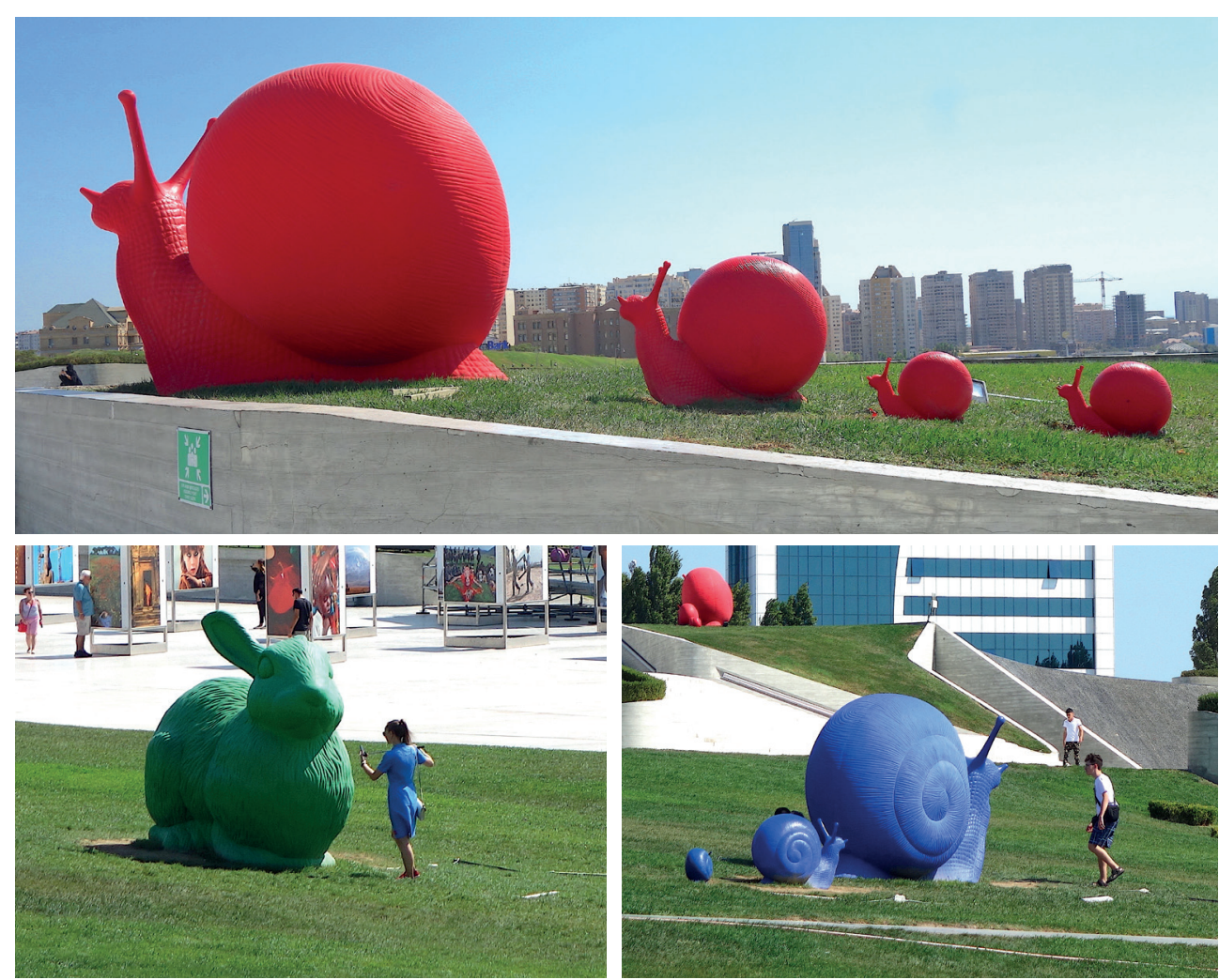

Fig. 7-9. Heydar Aliyev Center, design by Zaha Hadid; site detail. Photo by E. Kaczmarska, 2018

\section{The Flame Towers by HOK}

The Flame Towers - a complex of contemporary office towers, have likewise become an important symbol of Baku. They are excellent representatives of the strategy that the government of Azerbaijan has adopted for Baku. The city, by using its petrodollars, wants to quickly create a global tourist destination similar to the UAE's Dubai. Using spectacular architecture that meets various expectations (in aesthetic and functional aspects), this plan is consistently being implemented ${ }^{5}[11]$.

Azerbaijan has been known as the Land of Fire. The flame in the name of the complex is a reference to the tradition of pillars of fire that have been emerging from the ground since ancient times across the entire area of the Absheron Peninsula, primarily around its coastal

5 The construction of the Flame Towers - an unquestionable symbol, and the construction of the Heydar Aliyev Centre - a building that is more refined in its appearance and function and attracts a different type of recipient, the organisation of international mass events like the Eurovision Song Contest (the construction of Cristall Hall), Formula 1 races, etc. All these efforts carry over to the visibility of the country in the media and increased tourist interest. Following Dubai's model includes the currently halted Khazar project featuring the construction of artificial islands around $25 \mathrm{~km}$ to the south-west from Baku. It is currently difficult to assess whether the intended effect can be fully obtained, particularly as the determinants of the expansion of Dubai and Baku are different; however, the current aesthetic outcome within the urbanised space of Azerbaijan's capital is undeniable [11]. 
area. However, we should also note the Ateshgah fire temple and Yanar Dag, the 'burning mountain' near the country's capital, where natural gas has been leaking for thousands of years. These sites were holy to Zoroastrian fire worshippers.

In the area of the contemporary city, the futuristic towers are a modern equivalent to the thirty-metres-tall Maiden Tower (seventh-twelfth century AD) - the ancient symbol of İçərişəhər, the Inner City. This tower - and around fifteen others that have survived in Azerbaijan - was a defensive structure in the past. It is a valuable monument, the most famous vertical element of the historic centre. In 2000, it was inscribed onto the UNESCO World Heritage Sites List along with other monuments of the Old Town.

Tower-building traditions are also linked with drilling towers, which were erected in association with oil and natural gas mining towards the end of the nineteenth century. The country's economic boom contributed to the change in the city's image. Numerous palaces, villas and elegant townhouses were built, new avenues were delineated along with a seaside promenade and an accompanying park. Baku transformed into a modern city with a grid of streets, broad walkways and formal squares. The compact development spread amphitheatrically across the undulating coast of the Bay of Biscay. The mining of natural resources was a foundation for many fortunes. ${ }^{6}$ During this period, the entire Absheron Peninsula and the immediate vicinity of Baku became dotted with drilling towers and pumpjacks. Surviving postcards are an interesting document of the landscape of these resource-mining areas. Small escarpments in various locations across the peninsulas are still burning, while small volcanic cones pour out hot mud saturated with the smell of oil.

6 Businessmen from the oil sector from all over the world (e.g. the Nobel brothers, Rothschild) gained their riches here; some competed with each other by wide-ranging charity and patronage of culture and the arts. Of note is Hacı Zeynalabdin Tağıyev and his efforts to ensure the comprehensive development of Baku and the city's community. These included efforts and financial contributions to building the city's waterworks, making the capital's streets greener and better illuminated. Outstanding architects from the period were commissioned to design important public buildings. These architects were mostly Poles: Józef Płoszko, Eugeniusz Skibinski, Kazimierz Skórewicz, Józef Gosławski and Konstanty Borisoglebski. Most of their works were in the Secession style, enriched with Moorish, Romanesque and Gothic elements [2]. 


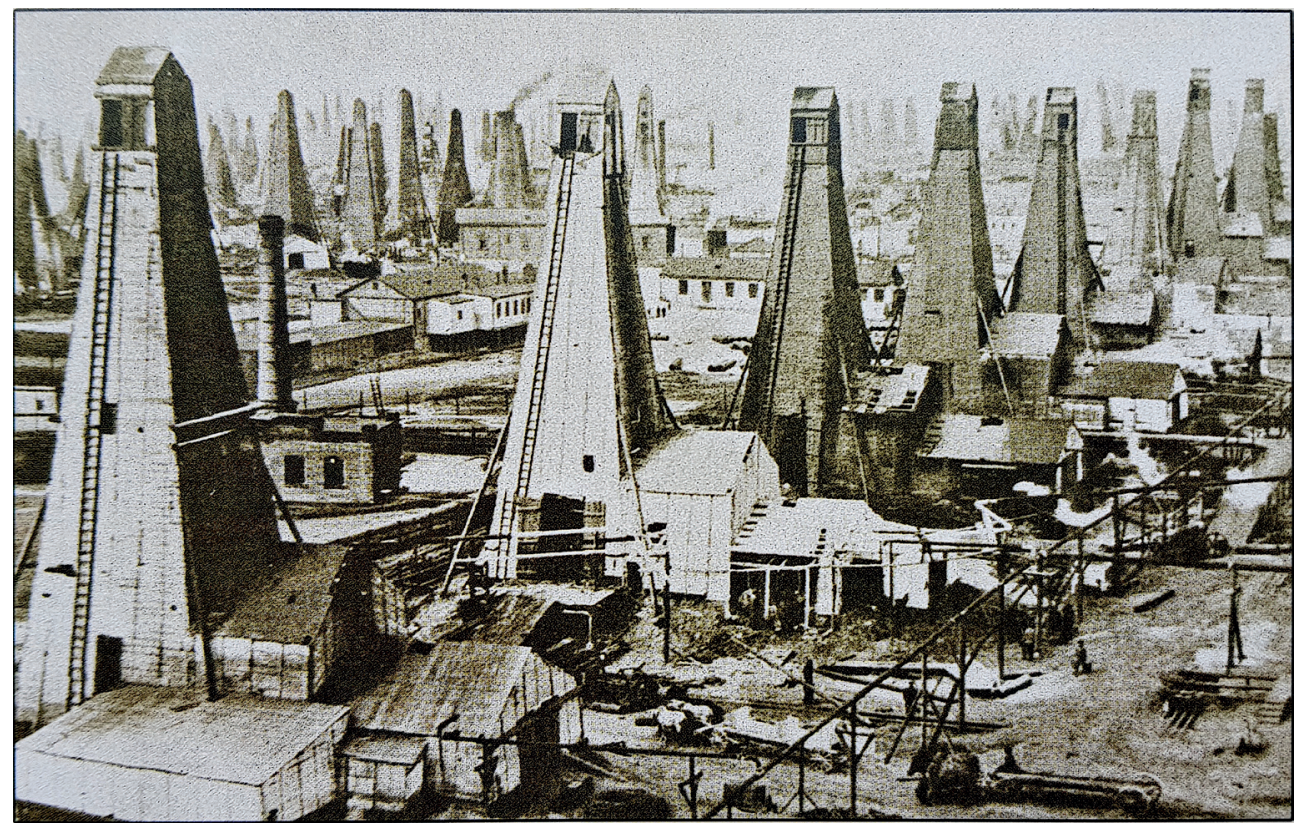

Fig. 10. Towards the end of the nineteenth century, the entire Absheron Peninsula and the immediate surroundings of Baku became dotted with drilling towers and pumpjacks [from:] Old Baku. Oil Production, Project of Khanlar Mamedov, 2011

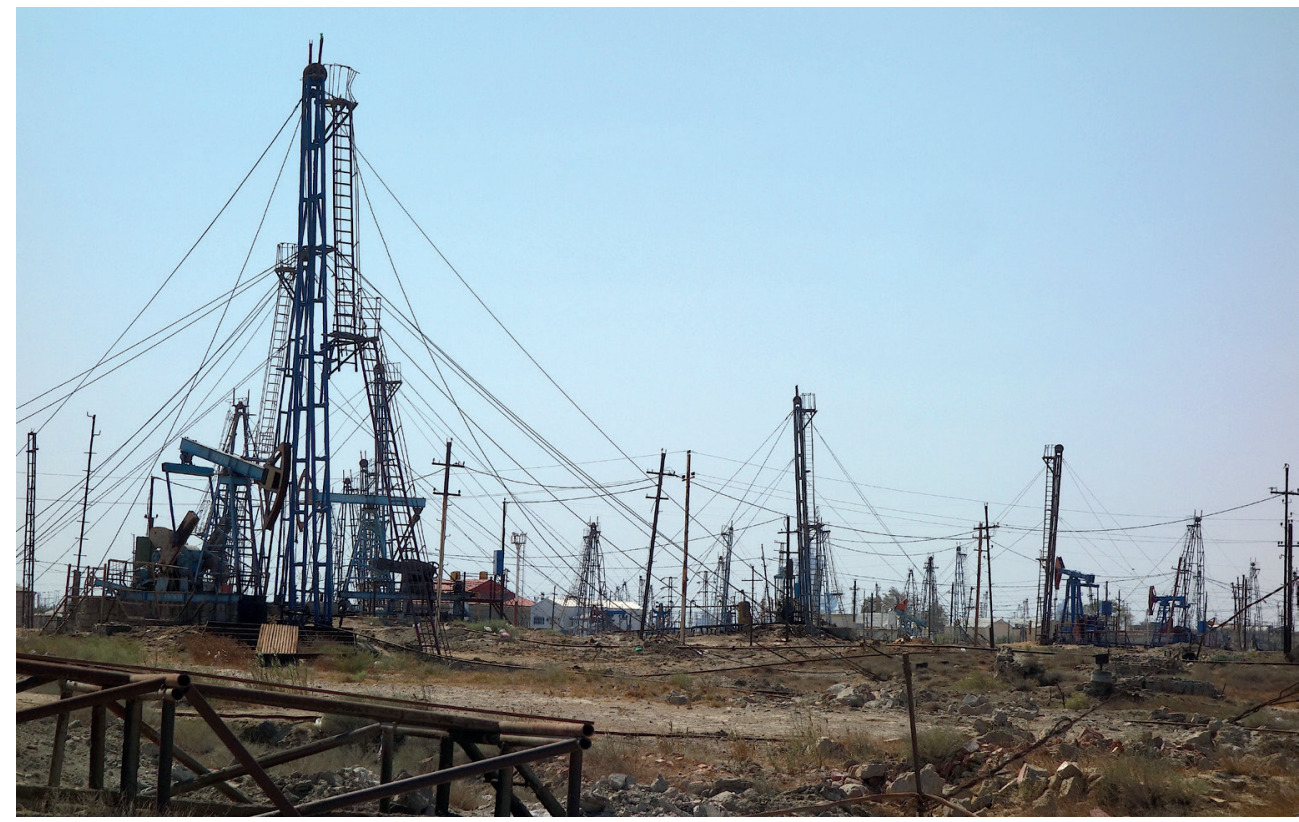

Fig. 11. The present-day appearance of the general area of Baku has not changed much since the nineteenth century. Photo by E. Kaczmarska, 2011 
The towers in question are three, similar buildings of varying height (190 metres, 160 metres and 140 metres) and atypical, slightly bent silhouettes modelled after flames and clad in a 'shining skin'. They were sited near Baku's Old Town, to its west, in the direct vicinity of the Path of Martyrs. The tallest building of the complex, the thirty-nine-storey southern tower, houses apartments; the thirty-six-storey northern tower is a hotel, while the western one has office spaces. They were designed by HOK and, after five years of construction, were opened in 2013 [12]. They are monumental, vertical giants, visible from every part of the city - they form its new, contemporary panorama while also referencing tradition and history. Perhaps this is why these symbols were copied in another complex of buildings at Neftchiler Avenue, as evidenced by the structures of new colossal buildings being erected along the avenue ${ }^{7}[13]$. These buildings are overbearing in terms of scale, although they do have a discrete charm, grace and originality.

7 In 1997, the Baku promenade was placed by Heydar Aliyev on a list of strategic places for the city's development and gained a new status and a new name (Primorsky Park). The costly revitalisation of state property began in 2007, and has been publically funded and managed by the Council of Ministers. The municipal administration does not have much say in these matters. Previously unintended divisions into a high-class west and a low-class east began to appear across the promenade. The eastern side is slowly being characterised as 'unprepared for urban life' [13]. 

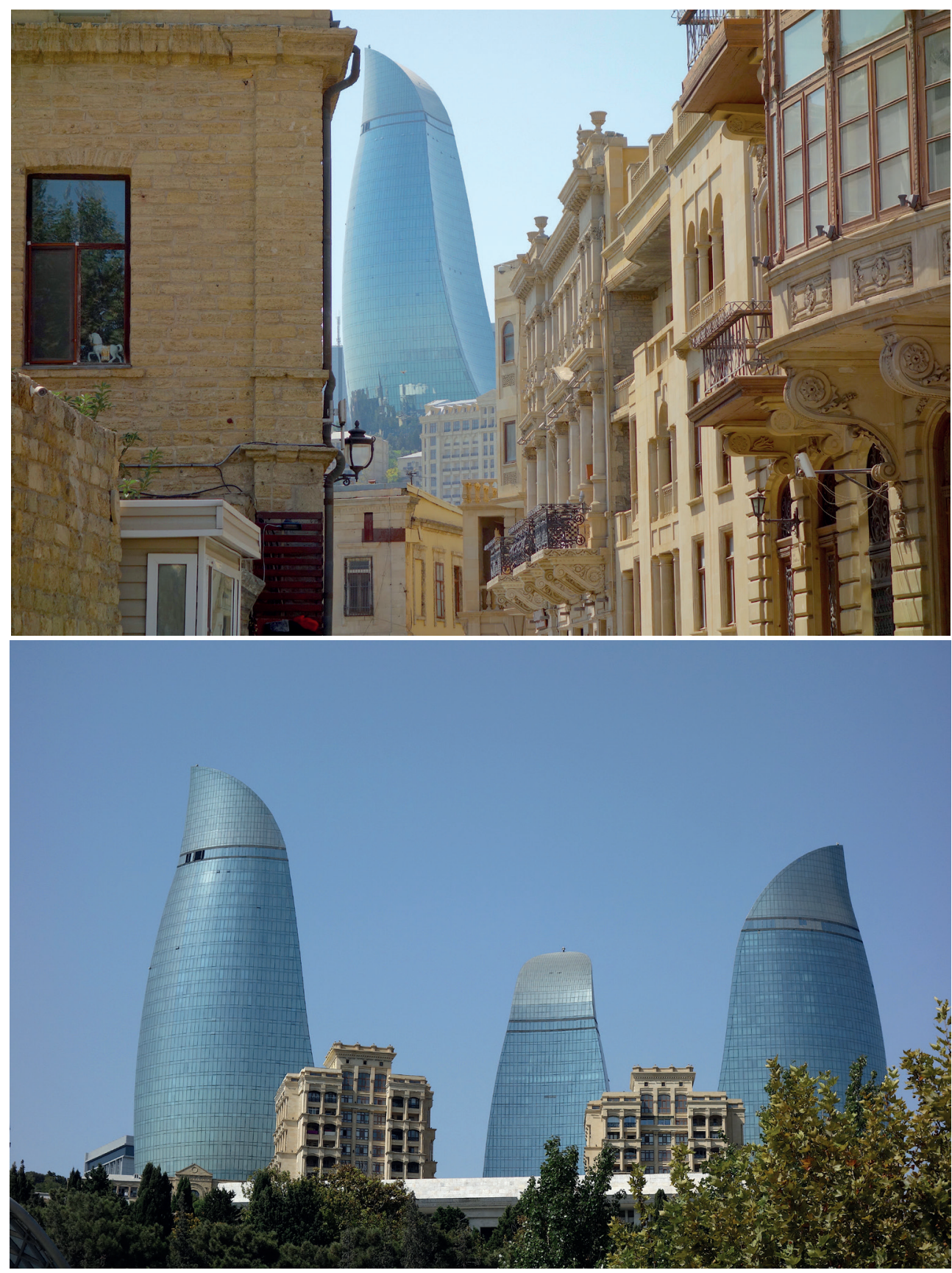

Fig. 12-13. Flame Towers dominating the skyline of Baku in a view from the interior of urban tissue and in the perspective of the horizon, design by HOK. Photo by E. Kaczmarska 
The application of LED lights on the surfaces of the towers enabled an extraordinarily attractive spectacle that is presented to residents and tourists every night after sunset. It references the concept of towers that symbolise flames. When seen from the Caspian boulevard or a ship on 'oil lake', it is an array of point lights that dance on the building's facades and rhythmically pulsate in the intensive colours of Azerbaijan's flag, with a figurative, educational message. The reflections of this spectacle on the calm waters of the Caspian Sea only intensify the aesthetic experiences of this event. The display was acknowledged as the best illumination in the world.

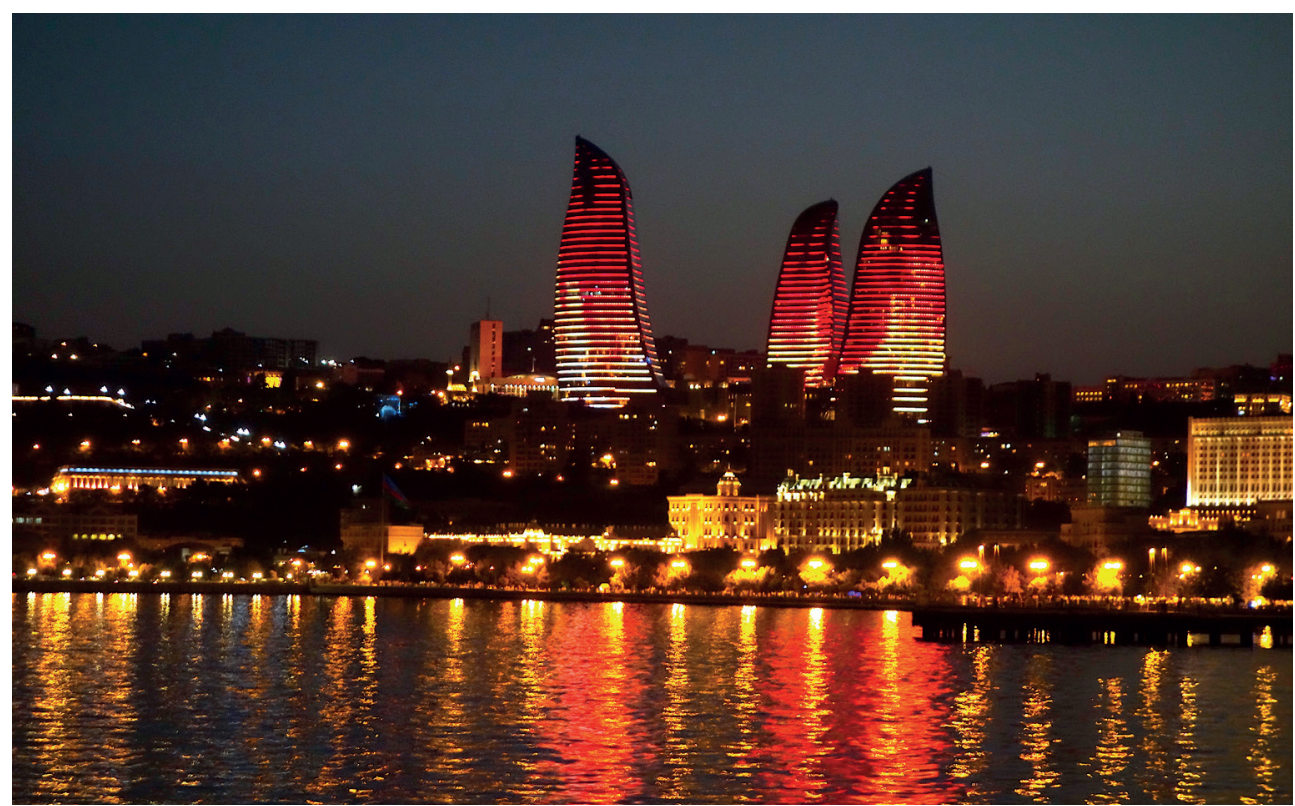

Fig. 14. The light spectacle on the facades of the Flame Towers. Photo by E. Kaczmarska

\section{Conclusions}

The places presented in the paper are important symbols of modern Azerbaijan and its capital, Baku. The fact that this country-located at the crossing of Eurasia's most important routes and the most ethnically diverse state in the entire Caucasus - has clear political and economic goals, and an ambition to become a dominant force within the region. It is a great synthesis of various cultures and places that connect the East with the West. The capital of Azerbaijan-Baku - makes effective use of this, combining magic, the mysticism of fire and the charming atmosphere of the orient with the pragmatism and engineering knowledge of the West.

\section{References}

[1] Świętochowski T., Azerbejdżan i Rosja; Kolonializm, Islam i Narodowość w podzielonym kraju, Instytut Nauk Politycznych PAN, Warszawa 1998

[2] Azerbejdżan. Panorama turystyczna. Przewodnik. Oficyna Wydawnicza Rewasz, Pruszków 2014.

[3] Baku Research Institute, 2020. Available: https://bakuresearchinstitute.org [Accessed: 30 Apr 2020] 
[4] Melvyn G. et al., "Azerbaijan”, in Encyclopaedia Britannica, Encyclopædia Britannica, inc., 2019. Available: https://www.britannica.com/place/Azerbaijan [Accessed: 30 Apr 2020]

[5] The Editors of Encyclopaedia Britannica, "Baku", in Encyclopaedia Britannica, Encyclopædia Britannica, inc., 2019. Available: https://www.britannica.com/place/Baku [Accessed: 30.04.2020]

[6] Guliyev F., Urban Planning in Baku: Who is Involved and How It Works By, 2018 [in:] Urbanization and Urban Public Policy in Baku, Caucasus Analytical Digest, No 101, 2018

[7] Azerbaijan State Statistical Committee. Available: http://www.stat.gov.az/source/construction/?lang=en $>$ [Accessed: 30 Apr 2020]

[8] Zaha Hadid Architects, Heydar Aliyev Centre. Available: https://www.zaha-hadid.com/architecture/ heydar-aliyev-centre/ [Accessed: 30 Apr 2020]

[9] Bianchini R., Heydar Aliyev Center - Baku., 2019. Available: https://www.inexhibit.com/mymuseum/heydar-aliyev-center-baku-azerbaijan-zaha-hadid/ [Accessed: 19 Dec 2018]

[10] Muratorplus.pl, Centrum Hejdara Alijewa w Baku, 2016. Available: https://www.muratorplus.pl/ inwestycje/inwestycje-publiczne/centrum-hejdara-alijewa-w-baku-aa-yREp-sF5L-4MkQ.html [Accessed: 19 Dec 2018]

[11] Valiyev A., "Baku's Quest to Become a Major City: Did the Dubai Model Work?", in Urbanization and Urban Public Policy in Baku, Caucasus Analytical Digest, no 101, 2018.

[12] HOK, Baku Flame Towers. Available: https://www.hok.com/projects/view/baku-flame-towers/ [Accessed: 30 Apr 2020]

[13] Darieva T., Reconfiguring a Public Place. Baku Promenade between Europe and Asia, 2011, based on Darieva T., A Remarkable Gift in a Postcolonial City: The Past and Present of Baku Promenade, in Urban Spaces after Socialism: Ethnographies of Public Places in Eurasian Cities (ed.) Tsypylma Darieva, Wolfgang Kaschuba, and Melanie Krebs, Frankfurt: Campus Verlag, 2011. 
